NBER WORKING PAPER SERIES

\title{
THE IMPACT OF CHILD SUPPORT ENFORCEMENT ON FERTILITY, PARENTAL INVESTMENT AND \\ CHILD WELL-BEING
}

\author{
Anna Aizer \\ Sara McLanahan \\ Working Paper 11522 \\ http://www.nber.org/papers/w11522
NATIONAL BUREAU OF ECONOMIC RESEARCH
1050 Massachusetts Avenue
Cambridge, MA 02138
July 2005

The authors would like to thank Jeanette Chung, Janet Currie, Pedro Dal Bó, Angie Fertig, Len Lopoo, Irv Garfunkel, Princeton University seminar participants and the MacArthur Network on the Family and the Economy for useful comments. The authors would also like to thank the Bendheim-Thomas Center for Research on Child Wellbeing at Princeton University which is supported by grant 5 R01 HD36916 from the NICHD and the Office of Population Research at Princeton University which is supported by grant 5 P30 HD32030 from the NICHD and the Center for Health and Well-Being at Princeton University. The data used in this article can be obtained from Anna Aizer. The views expressed herein are those of the author(s) and do not necessarily reflect the views of the National Bureau of Economic Research.

(O2005 by Anna Aizer and Sara McLanahan. All rights reserved. Short sections of text, not to exceed two paragraphs, may be quoted without explicit permission provided that full credit, including $\odot$ notice, is given to the source. 
The Impact of Child Support Enforcement on Fertility, Parental Investment and Child WellBeing

Anna Aizer and Sara McLanahan

NBER Working Paper No. 11522

July 2005

JEL No. J12, J13, I38

\begin{abstract}
Increasing the probability of paying child support, in addition to increasing resources available for investment in children, may also alter the incentives faced by men to have children out of wedlock. We find that strengthening child support enforcement leads men to have fewer out-of-wedlock births and among those who do become fathers, to do so with more educated women and those with a higher propensity to invest in children. Thus, policies that compel men to pay child support may affect child outcomes through two pathways: an increase in financial resources and a birth selection process.
\end{abstract}

\author{
Anna Aizer \\ Brown University \\ Department of Economics \\ 64 Waterman Street \\ Providence, RI 02912 \\ and NBER \\ aizer@brown.edu \\ Sara McLanahan \\ Office of Population Research \\ Princeton University \\ Wallace Hall \\ Princeton, NJ 08544 \\ mclanaha@princeton.edu
}




\section{Introduction}

Between 1970 and 1989, the proportion of children living in poverty grew by nearly one third, with most of the increase attributable to the increase in single-mother families (Lerman, 1993). In response to these changes, and in an effort to compel absent fathers to provide financially for their children, federal and state government officials began pursuing policies designed to strengthen child support enforcement. Not only have child support payments increased during the past twenty years (Case, Lin, and McLanahan 2003), but income from child support appears to have beneficial effects on children over and above income from other sources (Knox, and Bane 1994; Graham, Beller, and Hernandez 1994; Knox 1996). To account for the latter, researchers hypothesize five potential mechanisms: 1) child support income is more likely to be spent on children, as compared with other income, 2) child support alters family dynamics (between mothers and fathers) in a positive way, 3) child support reduces mothers' reliance on welfare and increases employment and marriage, 4) mothers invest more in their children as a signal to absent fathers of their commitment to the child in order to obtain more child support in the future, and finally 5) child support is positively correlated with father-involvement and commitment to the child. The first four mechanisms are typically characterized as causal, while the last is considered a selection effect (Argys, Peters, Brooks-Gunn, and Smith 1998).

Attempts to distinguish among the five mechanisms have been hampered by the difficulties inherent in empirically identifying the separate effects. ${ }^{1}$ We posit an

1 Del Boca and Flinn (1994) find evidence using consumer expenditure data that the share of expenditures on child goods and services increases as the share of income from child support increases among divorced mothers. Hernandez, Beller, and Graham (1995) identify the impact of income separate from father 
alternative explanation that can be identified empirically - that stricter child support enforcement creates incentives for men to have fewer children outside marriage, and for those who do, to partner with women who are more likely to invest in their children independent of child support receipt. Thus unlike previous research that posits either a causal effect or selection, we posit that stricter child support enforcement causes positive selection on the maternal quality where quality refers to a mother's own level of human capital and propensity to invest in her children. As such, we might expect current policies of stricter child support enforcement to have positive effects on both present and future child outcomes. Positive maternal selection also provides theoretical support for two of the five previously mentioned mechanisms (that child support income is more likely to be spent on the child and that child support may reduce reliance on welfare) since higher quality mothers are more likely to invest in their children and less likely to rely on welfare.

In the first part of this paper we discuss the incentives generated by stricter child support enforcement policies, how they affect the fertility of single women, and how they change the average underlying characteristics of single mothers. The discussion incorporates the interaction between state policies of stricter child support enforcement and the major public program serving single women with children- the AFDC program. We predict that under certain assumptions, increasing the probability that fathers will be required to pay child support results in 1) fewer children born to mothers who are most

involvement by comparing the impact of child support in a period in which fathers' contributions were more likely voluntary (because of lax enforcement) with a period of strong enforcement in which fathers were more likely compelled (and therefore more reluctant). They find that as enforcement increases, the positive impact of child support on education declines, suggesting that previous estimates of child support reflect, in part, unobserved characteristics of fathers who voluntarily contribute. 
likely to use AFDC, and 2) more births to women with a higher underlying propensity to invest in children.

The intuition behind the first prediction is based on the fact that all child support payments received by women on welfare are taxed nearly 100 percent by the state. Thus stricter enforcement does not provide single women who are likely to rely on welfare with incentives to have children. In contrast, stricter enforcement provides men with clear disincentives to have children, especially if their payments go to the state rather than to the mother of their child. The intuition behind the second prediction that stricter child support enforcement will lead to a change in the underlying composition of single women is that, given men's inability to control how their child support dollars are spent (on the child or the mother), stronger child support enforcement provides them with an incentive to have children with women who have a greater underlying preference for investing in children.

In the second part of this paper we provide empirical support for the two predictions of the model and employ an identification strategy that enables us to isolate this particular mechanism empirically. First, we use annual data on state expenditures for child support enforcement and on natality for the period 1985-1998 to estimate the impact of increasing the probability that fathers will have to pay child support on nonmarital child bearing and maternal investments in children born outside marriage. ${ }^{2} \mathrm{We}$ find that more stringent child support enforcement results in fewer births, especially among less educated single women, and, conditional on education, greater use of early prenatal care (a measure of the underlying propensity to invest in children), both of

2 We chose 1984 as the starting year because it is the first year in which the CDC natality files include the universe of births, not a sample. 
which suggest positive selection on maternal quality. ${ }^{3}$ By focusing on the impact of increases in state expenditures on child support enforcement that were largely driven by federal legislation (as opposed to state laws), and by using a within state difference-indifference framework that enables us to control for factors that vary at the state-year and that might be correlated with both child support enforcement and fertility, we limit the potential for policy endogeneity bias in the findings. And because our measure of maternal investment is prenatal care which is initiated prior to the receipt of any child support, any positive impact of child support enforcement on this measure of maternal investment is unlikely related to an increase in available financial resources.

The findings that stricter child support enforcement leads to a decline in the number of out of wedlock births and an average increase in both maternal education and child investment suggests positive selection on maternal quality as hypothesized. However, it does not rule out alternative mechanisms. Two alternative mechanisms that would give rise to similar empirical findings are 1) fathers who anticipate child support obligations in the future will (voluntarily) provide financial support to mothers during the prenatal period in order to increase mothers' own prenatal investments in the child, and 2) mothers who anticipate child support payments in the future will experience an increase in their permanent income that enables them to increase their prenatal investments by borrowing against future child support payments. These two mechanisms may be classified as income effects as opposed to a composition or selection effect.

3 These findings do not support the theory proposed by Auginbaugh (2001) that child achievement signals a higher propensity for child investment and thus leads to an increase in future child support receipt. This theory would predict a decline in maternal prenatal investment as a result of the increased probability of child support receipt as there would be less need to signal because men would be more likely to be compelled to pay child support. That is, under strict child support enforcement, women would not have to rely on voluntary support and thus would have less need to signal in order to gain support. 
To determine whether either of these two mechanisms is operating, we use data from the Fragile Families and Child Wellbeing Study, a longitudinal survey of new mothers that includes information on future child support, receipt of financial assistance during the prenatal period, prenatal investments (by mothers and fathers) and mothers' ability to borrow. We find that mothers who receive child support at year one are more likely to make greater prenatal investments. However, even when we condition on prenatal financial transfers from the father, the positive impact of future child support on maternal investment in the prenatal period remains. That is, even among mothers who receive no prenatal transfers, those with future child support payments are still more likely to invest in the prenatal period. This finding is inconsistent with the first mechanism - that fathers who expect to pay child support in the future will invest more during the prenatal period which enables mothers to invest more in prenatal care.

Nor do we find evidence to support the second mechanism - that mothers who receive child support in the future will invest more in prenatal care because they are able to borrow against future child support payments. We find no difference in the impact of future child support receipt on prenatal investment between mothers who are able to borrow and those who are not. The results from the Fragile Families data suggest that selection on fertility, rather than an income effect, is driving the finding that increases in the probability of future child support payments lead to an increase in the average probability of maternal prenatal investment in children.

Our analysis has implications for a broad range of research that examines the effect of policies on child outcomes. Insofar as policies affect fertility decisions as well 
as subsequent parental behavior and child outcomes, failing to take account of the former may lead to incorrect estimates of the true effect of the policies.

The rest of the paper is laid out as follows. In section II, we explore the incentive effects of stricter child support enforcement and their implications in terms of potential selection on the birth mother and review the relevant literature. In section III we discuss our identification strategy and present the results from the aggregate state-level analysis of births from vital statistics data. In section IV we present results from the Fragile Families analyses, which explores the mechanism(s) behind the finding that more stringent child support enforcement leads to increased prenatal investment. Section V concludes by discussing the implications of our findings regarding estimation of the impact of child support on child wellbeing.

\section{Incentive Effects of Stricter Child Support Enforcement}

A. Impact of stricter Child Support Enforcement on Fertility - Background Literature Theoretical predictions of the impact of stricter child support enforcement (CSE) on the number of births or composition of parents are ambiguous. On the one hand, stricter CSE raises the financial obligation of the absent father to the mother, raising the cost to single fathers of having children. On the other hand, stricter CSE lowers the cost of having children faced by single mothers. While the former should lead to a decline in out of wedlock births, the latter should lead to an increase; so that the net effect of stricter CSE on fertility is ambiguous a priori. 
The empirical evidence with respect to the impact of child support enforcement on fertility suggests that the incentive effects of stricter CSE for men outweigh those for women: states with stricter child support enforcement have witnessed a decline in out-of wedlock births. ${ }^{4}$ These studies rely on changes in state laws governing child support enforcement (paternity establishment, immediate withholding, etc.) to identify the impact of stricter child support enforcement on fertility. ${ }^{5}$ Examples of this literature include Sonenstein, Pleck, and Ku (1994) who find that adolescent males are aware of paternity establishment policies and modify their sexual behavior and contraceptive use accordingly. Garfinkel and his colleagues (Garfinkel, Huang, McLanahan, and Gaylin 2003; Plotnick, Garfinkel, McLanahan, and Ku 2004) who link higher paternity establishment rates to non marital child bearing and find that higher paternity establishment rates reduce non-marital child. Though most of these studies employ state and year fixed effects, endogeneity of the child support enforcement policies still poses a problem if the timing of the policies within each state is driven by unobservable characteristics related to fertility and nonmarital child bearing that are changing over time. We address the potential policy endogeneity of stricter child support enforcement and describe our identification strategy in Section III.

\footnotetext{
4 Another possibility is that stricter CSE is not negatively affecting fertility, but positively affecting marriage if the cost of being a single father increases relative to being married. Heim (2003) finds no impact of child support enforcement on divorce rates; Nixon (1997) finds a negative relationship between child support enforcement and divorce as does Huang (2002). For our purposes, however, it doesn't matter which mechanism is responsible. Though it is interesting to note that if stricter CSE were lowering out of wedlock births by encouraging marriage (as opposed to lowering fertility), we would expect those marrying to come from the upper tail of the distribution of "quality" single mothers - that is, mothers with higher education. As such, the underlying quality/education of single mothers would decline. That is not what we find, suggesting that stricter child support enforcement in not affecting the composition of single mothers by increasing the incentives for marriage.

5 There also exists a literature linking increased child support enforcement with child support payments (Freeman and Waldfogel 1998; Argys, Peters, and Waldman 1995; Nixon 1994; Miller, Garfinkel, and McLanahan 1997; Beller and Graham 1991).
} 
While there is considerable empirical evidence regarding the impact of stricter CSE on fertility, there is no research on how child support affects the composition or quality of parents. We provide the first such empirical estimates of the impact of stricter CSE on the composition of mothers and thus the potential quality of parenting and child outcomes.

\section{B. Impact of Stricter Child Support Enforcement on Composition of Mothers}

A simple model of the decision of an unmarried couple to have a child illustrates how the composition of mothers may change if child support enforcement increases. In such a model, fathers' utility $\left(\mathrm{U}_{\mathrm{m}}\right)$ depends on their own consumption $\left(\mathrm{c}_{\mathrm{m}}\right)$ and the quality or capital of their children (q). Q increases with financial resources devoted to the child a fraction of both the mother's income $\left(I_{\mathrm{w}}\right)$ and any child support payments received (cs). Fathers choose their consumption level $\left(\mathrm{c}_{\mathrm{m}}\right)$ and how much child support to provide (cs). Likewise, mothers care about their own consumption $\left(\mathrm{c}_{\mathrm{w}}\right)$ and $\mathrm{q}$ and choose how much of $I_{w}$ and cs to invest in the child. Some mothers invest a greater portion of their income in their children than others. We can think of these mothers as having a greater preference for child quality, denoted $\alpha$.

Although a non-cohabitating father is unable to assure that all child support payments to the mother are spent on the child and not on her own consumption (Willis 1999), he may observe a mother's $\alpha$. Since $\alpha$ determines how much of her income and child support she will invest in her child, men will always prefer to have children with women with a greater $\alpha$. 
When deciding whether to have a child, a man will compare the indirect utility gained from not having a child (income spent on his consumption only) and having a child with a woman with a given $\alpha$ (income spent on consumption and child support). A critical level of $\alpha$ exists above which his utility from having a child exceeds that of not having one. This critical level increases with the probability that he will be forced to pay child support and with the probability that the woman will rely on welfare (AFDC/TANF). The intuition behind the latter is that, with some exceptions (some states allow for a $\$ 50$ pass through each month), most child support payments to mothers on welfare are taxed 100 percent by the state. As such, men receive little if any additional benefit (in the form of higher child quality) from their child support payments if the mother relies on welfare. ${ }^{6}$ Thus when forced to pay child support, men will want to have children with women with a greater $\alpha$ and when women are likely to use welfare, men will require an even higher $\alpha$ to have a child with her.

Figure 1 illustrates these points. In the figure, the horizontal line $\mathrm{U}_{\mathrm{m}}(\mathrm{NC})$ represents a father's utility associated with not having a child (NC). Utility does not change with $\alpha$ because it is only a function of income $\left(\mathrm{I}_{\mathrm{m}}\right)$. The dark line $\mathrm{U}_{\mathrm{m}}(\mathrm{C}, \mathrm{NE})$ represents a father's utility from having a child with no child support enforcement, and the line $\mathrm{U}_{\mathrm{m}}(\mathrm{C}, \mathrm{E})$ represents his utility from having a child with child support enforcement. $\alpha^{*}{ }_{\mathrm{NE}}$ represents the minimum $\alpha$ required for the utility of having a child to exceed that of not having one $\left(\mathrm{U}_{\mathrm{m}}(\mathrm{C}, \mathrm{NE})>\mathrm{U}_{\mathrm{m}}(\mathrm{NC})\right)$ under no enforcement. As is evident from the graph, this critical value is lower than that under enforcement $\alpha^{*}{ }_{\mathrm{NE}}<$

6 This argument presumes that welfare use has no independent effect on child investment or well-being. That is, a mother with a given $\alpha$ and income will invest the same amount in her child regardless of the source of income (earnings, child support, or welfare). Alternatively, one could argue that relying on welfare is a negative investment in the child and therefore negatively related to $\alpha$. This would amplify the results, providing an additional incentive for men to select with a women with a high $\alpha$. 
$\alpha^{*}$. The intuition behind this is simply that the constraint introduced by child support enforcement (if it is binding) lowers a father's utility for any given $\alpha$. The fourth line $\left(\mathrm{U}_{\mathrm{m}}(\mathrm{C}, \mathrm{E}, \mathrm{W})\right)$ represents the indirect utility associated with having a child with a woman on welfare under a regime of strict child support enforcement. The critical value $\alpha^{*}{ }_{\mathrm{EW}}$, above which men will choose to have children, is higher still.

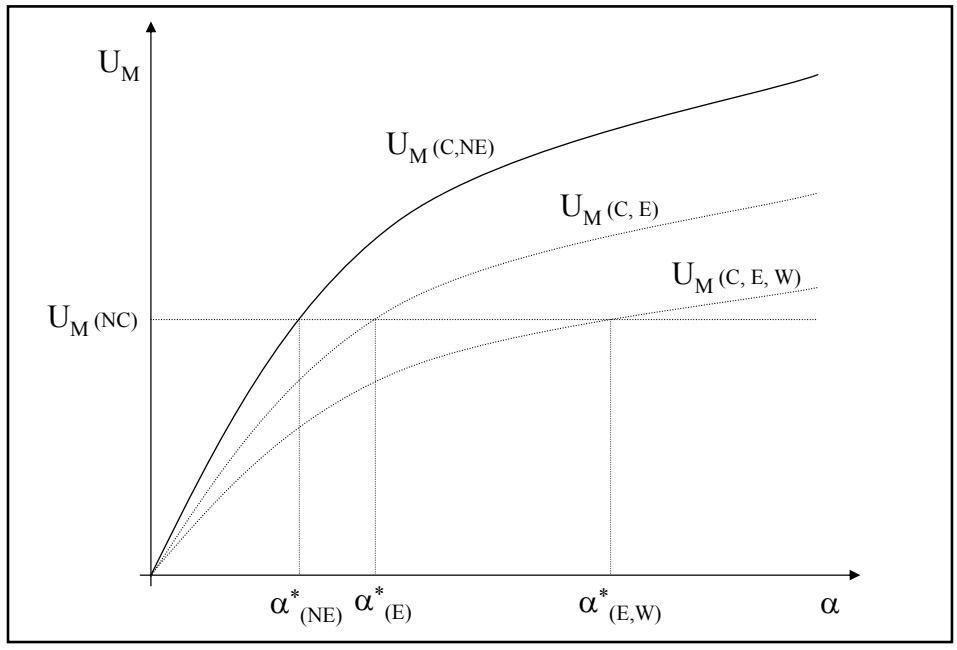

\section{Figure1}

Stricter Child Support Enforcement and the Composition of Mothers

III. Child Support Enforcement, Prenatal Investments and Birth Outcomes: Evidence from Vital Statistics Data

Our analysis of the impact of stricter child support enforcement on birth rates, prenatal investment and birth outcomes differs in important ways from previous research. Previous studies have examined the impact of state child support policies on the number of births among single mothers (Case 1998; Garfinkel, Huang, McLanahan, and Gaylin 2003). We are the first to examine the impact of stricter child support enforcement on the 
composition/quality of mothers (as measured by their educational attainment) and the prenatal investments they make in their children as measured by their early initiation of prenatal care and number of prenatal visits.

Another important distinction lies in our empirical methods. A major challenge of estimating the impact of stricter child support enforcement on fertility and maternal investment is to identify the effect of child support enforcement separate from other potentially unobservable factors that might affect both the state's child support policies and fertility or investment in children. Previous studies of the impact of child support enforcement policies on fertility attempt to control for unobserved influences using a variety of methods. Most compare changes in fertility over time between states that adopt stricter child support enforcement and those that do not (also referred to as a state fixed effect approach). This provides some control for policy endogeneity by controlling for state-level factors that are fixed and do not vary over time, but not factors that might vary within state over time. ${ }^{7}$ In this paper we adopt an alternative approach that controls for time-varying unobservable factors within a state that might affect child support enforcement and fertility/investment. Examples of such factors might include changes in society values and norms or changes in the availability and cost of contraception.

To do this we obtain within state difference-in-differences estimates of the effect of stricter child support enforcement. This estimate is obtained by defining two groups: a treatment or experimental group and a control group. Because state child support

7 Case (1998) is a notable exception. She explicitly recognizes this possibility in her investigation of the impact of laws establishing stricter child support enforcement on the number of out of wedlock births. In a simple OLS, she finds that the laws predict an increase in out of wedlock births. After instrumenting for the state laws using characteristics of the state legislatures, she finds that stricter child support enforcement does lead to a decline in out of wedlock births, though the results are not significant. Her results underscore the importance of controlling for policy endogeneity. 
enforcement expenditures target single women, we define single women as the treatment and married women as the control group. We therefore construct our estimates of the impact of stricter child support enforcement by comparing its impact on the fertility/investment decisions of single mothers relative to married mothers residing in the same state. The assumption of this identification strategy is that changes over time in the behavior of men and women that are unrelated to child support enforcement are common to single and married women. It also assumes that married women are unaffected by child support enforcement. While this assumption is restrictive, it is preferable to simply comparing fertility/investment decisions under strict child support enforcement regimes with those under more lenient regimes because it allows one to identify the effect of stricter child support enforcement separate from broader changes in social norms, the cost of investing in children or other factors as measured by the behavior of married women.

Since these single-married fertility/investment differentials can be computed within cells defined by state and year, our approach implicitly controls for all timevarying state specific factors by allowing us to include not only individual state and year fixed effects but state*year fixed effects (as discussed further in the next section). The state*year fixed effects subsume the individual state and year main effects so that they need not be included separately. In other words, the vector of state*year fixed effects includes individual state and year fixed effects as well as an interaction between them.

A. Data and Estimation 
Data on all births in the US come from the 1985 -1999 Natality Detail Files collected by the CDC. ${ }^{8}$ Summary statistics are provided in Appendix Tables 1 and 2. Rather than perform the analysis on a dataset of all individual births, we aggregated the data to the group level with groups defined by year, state, age group, race, education and marital status. ${ }^{9}$ We matched these data with data on child support enforcement by the year in which the child was conceived (calculated using gestational age and date of birth). Our measure of child support enforcement is expenditures on child support that come from the annual reports of the Office of Child Support Enforcement, US Department of Health and Human Services. This represents a departure from other work that has focused on either specific policies/laws with respect to child support enforcement and/or child support expenditures. We focus on expenditures for the following reasons: 1) previous work has found the data on child support policies to be "incomplete and in some places inconsistent" (Freeman, and Waldfogel 1998), and 2) there are multiple policies and laws that require selection of an arguably arbitrary subset. However, we do repeat the analysis with a single policy - whether child support is withheld from father's wages - and discuss those results in the following section.

The equation estimated takes the form:

$$
\begin{aligned}
& \mathrm{Y}_{\text {symrae }}=\beta_{1} \text { single }_{\mathrm{m}}+\beta_{2} \ln (\mathrm{CSE}) * \text { single }_{\mathrm{msy}-1}+\beta_{3} \text { Race }_{\mathrm{r}}+\beta_{4} \text { Education }_{\mathrm{e}} \\
& +\beta_{5} \text { Age }_{\mathrm{a}}+\beta_{6} \text { state }^{*} \text { year }_{\mathrm{sy}-1}+\varepsilon_{\text {symrae }}
\end{aligned}
$$

8 Beginning in 1985 , all births were included as part of the file. Prior to 1985 , only a random sample of births were included for some states. The final dataset includes all births conceived 1985-1998. However, we needed to use natality data from 1999 to calculate the total number of children that were conceived in 1998.

9 An example of a single group or cell would be all births to single white mothers age 20-29 in Montana in 1990. 
In the above equation CSE refers to the average annual expenditures in the state in the three years prior to the year of conception. We do this because we believe that the effects of increased child support enforcement are not immediate but are lagged, and also to further limit the potential for policy-endogeneity bias. Single is an indicator equal to one if the birth mother is single (representing the treatment group). Thus the coefficient on the term $\operatorname{lnCSE} *$ single $\left(\beta_{2}\right)$ represents the within state difference-in-differences estimate: the impact of the child support enforcement on single women relative to married women in states that experience large increases in CSE relative to those in states with small changes in CSE. The vector Race includes the dummy variables for the race of the mother (black, white, Hispanic, Asian, and other is the omitted group), the vector Age includes dummies for the age of the mother (teen, age 20-29, age 30-39, and age 40-55 is the omitted group) and Education includes the educational status of the mother (less than HS, HS, HS+). For this analysis, we dropped college educated mothers as single college educated mothers are quite rare and unrepresentative. Recall that because the data are aggregated to the cell level based on state, year, race, marital status, age and education, only binary indicators for these measures, not continuous variables, can be included.

As noted previously, the inclusion of state*year fixed effects subsumes individual state and year fixed effects, so they are not included separately in the analysis (in other words, they are included in the state*year fixed effects). ${ }^{10}$ Including state*year fixed effects also controls for all factors that may vary within states over time, such as

10 State*year fixed effects include individual state and year fixed effects. This is can be shown with the following short example. Consider two years and two states. If state*year fixed effects are included, there would be three dummies included: state $1 *$ year 1 , state $1 *$ year 2 and state $2 *$ year 1 (state $2 *$ year 2 is the omitted or reference category) which is the equivalent of two main effects and an interaction (we are grateful to the editor for suggesting this illustrative example). 
unemployment rates and AFDC benefits that may be correlated with both the state's child support policies and birth outcomes as well as any other factors that vary within state over time that affect the whole population. ${ }^{11}$ In addition, the vector of state*year fixed effects subsumes the main CSE term (since it varies by state and year) but not the term $\ln (\mathrm{CSE}) *$ single - enabling identification of the impact of CSE on birth outcomes.

The outcomes (Y) are the 1) $\log$ of the number of births, 2) the proportion of mothers in the cell who initiated prenatal care in the first trimester, 3) the average number of prenatal visits, and 4) the proportion of low birth weight (LBW) births. For the first of these, we also include the log of the number of women in the cell (the denominator) as a covariate and weight by the size of the denominator. ${ }^{12}$ For the second, third and fourth, we weight by the number of births in the cell.

\section{B. Results}

Estimates of the impact of CSE on the number of births are presented in Table 1. The first column displays estimates of the impact of stricter CSE on the number of births. Consistent with previous work, we find that stricter child support enforcement leads to a significant decline in births to single women relative to married women. The estimated coefficient $\beta_{2}(-0.033)$ can be interpreted as the elasticity of the birth rate with respect to changes in child support expenditures. That is, a one percent increase in expenditures leads to a decline in single (non-marital) fertility relative to marital fertility of 0.03

11 Expansions in the Medicaid program represent a change in policy that might be of particular concern with respect to improvement in birth outcomes over this period. Since Medicaid expansions were all implemented by 1986 we run the regressions a second time for the period 1987-1998 and get the same results.

12 The denominator (the number of women of a given race, education level, age and marital status in a given state) was calculated from the 1990 Census. 
percent. In the next three columns of Table 1, we examine whether stricter CSE differentially affects the fertility of some single women more than others, thereby potentially altering the average underlying characteristics of single mothers and their children. We previously predicted that the fertility of those single mothers most likely to use the AFDC program would decline relative to others. Though we do not have an exact measure of a woman's propensity to use welfare, we do have measures of maternal education, which is highly negatively correlated with welfare use. In columns 2-4 we present the results stratified by maternal education. Consistent with our prediction, stricter CSE appears to have the greatest negative impact on the fertility of the women who have the least education and therefore are most likely to use welfare. The estimated elasticity is -0.094 for women without a high school degree and -0.039 for women with a high school degree. In contrast, for women with some college, the elasticity is slightly positive (0.023).

In Table 2 we present estimates of the impact of stricter CSE on two measure of prenatal investments of mothers - early initiation of prenatal care and the number of prenatal visits. Column 1 presents estimates of the impact of increasing child support expenditures on the proportion of single mothers in the state that initiate care in the first trimester, controlling for age, education and race. We find that single women in states with stricter child support enforcement are more likely to initiate care in the first trimester. Over the period 1984-1998 the share of single women initiating care in the first trimester increased from 0.548 to 0.708 (see Appendix Table 2). Given that CSE increased on average 300 percent over this period, the estimated coefficient of 0.018 suggests that half of this increase can be attributed to the increase in child support 
enforcement. ${ }^{13}$ Similarly in column two we present results which suggest that the increase in child support enforcement also led to a positive and significant increase in the number of prenatal visits among single women and was responsible for 6 percent of the observed increase in prenatal visits over this period. Finally, in column three, we present results for LBW. The proportion of single women with LBW babies declined from 0.112 to 0.099 over this period. The results suggest that the increase in child support enforcement over this period explains 13 percent of this decline.

In Table 3, we present estimates of the impact of stricter child support enforcement on fertility, prenatal investment and birth outcomes stratified by race. For non-black mothers (columns 1-4), increasing expenditures on child support leads to a reduction in the number of births, an increase in the proportion of women initiating early prenatal care and the number of visits, and a decline in the proportion of LBW births. For black mothers, however, while the number of births decline and the proportion initiating prenatal care early increases as does the number of prenatal visits, birth outcomes do not appear to improve. For black mothers, we find no significant effect of child support enforcement on LBW.

To provide additional evidence in support of this finding, we also estimate a discrete time duration model of the impact of CSE on time until first birth, using data on individual women from the NLSY79. The NLSY79 consists of a nationally representative sample of 12,686 young men and women age 14-22 in 1979 interviewed annually from 1979 to 1994 and then biennially until 2000. The NLSY includes 6,283 women of whom 5,762 are included in this analysis (521 are excluded because they already had at

13 We obtain this by estimating the impact of the average increase in child support expenditures 1984-1998 (roughly 300 percent) on the increase in prenatal care as a percent of the total increase in prenatal care observed over this period. 
least one child by 1979). Individual data allow us to include additional controls that might affect fertility such as AFQT score (the score on the Armed Forces Qualifying Exam, a measure of cognitive ability), whether her mother worked when she was 14 years old and the highest grade completed by her mother.

Though sample sizes prevent us from obtaining precise estimates, the hazard models do suggest that the probability that single women will have a child in a given year, conditional on not having had a child to date, is lower in states that spend more on child support enforcement. Increasing expenditures on child support enforcement two standard deviations around the mean decreases the probability of birth for a single woman from 4.5 to 1.7 percent. ${ }^{14}$ We also find that though the likelihood of having a child decreases for single women when child support enforcement increases, it does so at a slower rate for those with more education. This is consistent with our findings based on aggregate birth certificate data: stricter child support enforcement has the greatest negative impact on the fertility of women most likely to use AFDC - those with the least education.

Our choice of expenditures as the measure of child support enforcement is subject to the criticism that it might be confounded with efficiency or with the difficulty of the caseload of delinquent fathers. If, for example, expenditures were confounded with 14 Results available upon request from the authors. 
efficiency, that is, greater expenditures in states with less efficient child support collection systems, then the results would be biased downward. Similarly, if expenditures were confounded with caseload difficulty, (that is, states that increase their expenditures are those that already collect from those least reluctant to contribute and are attempting to collect child support from more reluctant fathers) this might also bias our estimates downwards. On the other hand, if states with more efficient or less difficult caseloads spend more because the marginal benefit of expenditures is greater, then our results would be biased upward.

As a check, we estimate the impact of an alternative measure of child support enforcement - an indicator for enactment of a law that automatically withholds child support payments from the wages of absent fathers. While the withhold represents an alternative measure, it is still positively correlated with child support expenditures (as are other child support laws). We find that, for example, adoption of the automatic withhold would explain 36 percent of the increase in first trimester prenatal care (less than the 50 percent explained by the increase in child support enforcement expenditures). While the results are qualitatively similar, they suggest a possible small upward bias to the results based on child support expenditures.

IV. Child Support and Prenatal Investments: Evidence from the Fragile Families Study

In this section we investigate potential mechanisms behind our finding that increased child support enforcement leads to an increase in prenatal investment. In particular, we wish to know whether this increase is due to positive selection as we 
hypothesize or some alternative mechanism. Two possible alternative mechanisms include: 1) increases in paternal income transfers during the prenatal period (in anticipation of future support obligations), and 2) increases in mother's ability to borrow against future child support payments during the prenatal period (as a result of a positive permanent income effect). We use data from the Fragile Families Study to determine to what extent the increase may be attributed to either of these two alternative mechanisms. Lack of evidence for either of these mechanisms would provide yet further support for our hypothesis of positive selection.

\section{A. The Fragile Families Data}

The Fragile Families and Child Well Being Study interviews approximately 3700 new unwed couples residing in 20 cities in 15 states shortly after the birth of their child. Parents are interviewed again when the child is between 12 and 18 months old. About 1900 of these parents were not co-habiting at the time of the follow-up interview and therefore were eligible for child support and inclusion in our sample. A unique aspect of the Fragile Families data is the extensive information (taken from both maternal and paternal surveys) on non co-habiting fathers.

These data include information on whether a formal or informal child support agreement exists at 12-18 months (34 percent). These data also include information on child investments during the prenatal period: the date when the mother initiated prenatal care and whether the father provided financial assistance to her during this period. Lastly, the data contain information on whether the mothers can borrow money (at least \$200) if they need to - a measure of their credit constraint. 


\section{B. Results from Fragile Families}

In the first two columns of Table 4 we present evidence regarding the impact of future child support receipt and prenatal transfers on prenatal investments. In the first column we explore the relationship between future child support receipt and early initiation of prenatal care. We find that those mothers who receive future child support are more likely to initiate prenatal care early (0.085), as expected. Even when we control for whether prenatal transfers were received from the father in column 2 , the positive effect of future child support receipt remains (0.080), suggesting that the receipt of prenatal transfers cannot explain the positive impact of future child support receipt on prenatal investments. In results not presented, we find that the same pattern emerges for LBW: future child support receipt leads to a decline in LBW and the effect remains even when we control for prenatal transfers, but the effects are imprecisely estimated, most likely due to small sample sizes.

To rule out the possibility that in anticipation of future child support payments, mothers are able to borrow additional money during the prenatal period (a permanent income effect), we stratify the sample based on whether the mother is credit constrained using the above-mentioned measure of credit constraint. The results are presented in columns 3 and 4 . If it were the case that future child support receipt positively affects maternal prenatal investment because the mother is able to borrow against future child support payments, then the positive impact of future child support receipt would be limited to (or at least stronger for) mothers who are not credit constrained. The empirical evidence from the Fragile Families does not support this, but rather rules out the idea that 
the empirical findings based on the birth certificate data were simply due to increased resources, not positive selection.

V. Discussion

This paper is the first to examine how the composition of mothers changes in response to an increase in the probability of future child support payments brought about by stricter state child support enforcement. We find that the average education of mothers increases, as does the level of maternal investments in children (as measured by early investment in prenatal care), with stronger child support enforcement. What is notable about these results is that the increase in maternal investment occurs prior to the receipt of any child support payments, suggesting that stricter child support enforcement, in addition to increasing the material resources available to children, may benefit children through a birth selection process. That is, stricter child support enforcement reduces fertility, especially among mothers who are less likely to invest in their children, regardless of actual child support receipt. As a result, we might expect current policies of child support enforcement to affect both current and future child outcomes. Existing research on the impact of child support receipt on child outcomes has not considered this mechanism. To fully understand the impact of any changes in state policies affecting child support enforcement on child outcomes, it is necessary to understand how policies might affect both the birth selection process as well as the receipt of financial resources, conditional on the birth of the child. 
References

Argys, Laura, Elizabeth Peters, Jeanne Brooks-Gunn, and Judith Smith. 1998. "The Impact of Child Support on Cognitive Outcomes of Young Children." Demography. 35(2): 159-173.

Argys, Laura, Elizabeth Peters, and Donald Waldman.1995. "Can the Family Support Act Put Some Life Back Into Deadbeat Dads? An Analysis of Child-Support Guidelines, Award Rates, and Levels." The Journal of Human Resources 36(2):226-252.

Auginbaugh, Alison. 2001. "Signals of Child Achievement as Determinants of Child Support." American Economic Review Papers and Proceedings 91(2): 140-144.

Beller, Andrea, and John Graham. 1991. "The Effect of Child Support Enforcement on Child Support Payments." Population Research and Policy Revew10:91-116.

Case, Anne. 1998. "The Effects of Stronger Child Support Enforcement on Non-Marital Fertility." In Fathers Under Fire: The Revolution in Child Support Enforcement, eds. Irwin Garfinkel, Sara McLanahan, Daniel Meyer, and Judith Seltzer, 191125. New York: Russell Sage Foundation.

Case, Anne, I-Fen Lin, and Sara McLanahan. 2003. "Explaining Trends in Child Support: Economic, Demographic, and Policy Effects.” Demography 40(1): 171-189.

Del Boca, Daniela, and Christopher Flinn. 1994. "Expenditure Decisions of Divorced Mothers and Income Composition." Journal of Human Resources 29(3): 742761.

Freeman, Richard, and Jane Waldfogel. 1998. "Dunning Delinquent Dads: The Effect of Child Support Enforcement Policy on Child Support Receipt by Never Married Women.” NBER working paper 6664.

Garfinkel, Irwin, Daniel Gaylin, Chung Huang, and Sara McLanahan. 2003. "Will Child Support Enforcement Reduce Nonmarital Childbearing." Journal of Population Economics. 16: 55-70.

Hernandez, Pedro, Andrea Beller and John Graham. 1995."Changes in the Relationship Between Child Support Payment and Educational Attainment of Offspring, 1979-1988." Demography 32(2):249-259.

Heim, Bradley. 2003. "Does Child Support Enforcement Reduce Divorce Rates? A Reexamination." Journal of Human Resources 38(4): 773-791.

Huang, Chien-Chung. 2002. "The Impact of Child Support Enforcement on Nonmarital and Marital Births: Does It Differ by Racial and Age Groups?" Social Service Review 76(2): 275-301. 
Knox, Virgina, and Mary Jo Bane. 1991. "Child Support and Schooling." In Child Support and Child well-Being, eds. Irwin Grafinkel, Sara McLanahan, and Philip Robins, 285-316. Washington DC: The Urban Institute Press.

Knox, Virginia. 1996. "The Effects of Child Support Payments on Developmental Outcomes for Elementary School-Age Children." The Journal of Human Resources. 31 (4):816-840.

Lerman, Robert. 1993. "Policy Watch: Child Support Policies." Journal of Economic Perspectives. 7(3):171-182.

Miller, Cynthia, Irwin Garfinkel, and Sara McLanahan. 1997. "Child Support in the U.S.: Can Fathers Afford to Pay More?" Review of Income and Wealth 43(3): 261-281.

Nixon, Lucia. 1997. "The Effect of Child Support Enforcement on Marital Dissolution." Journal of Human Resources 32(1): 159-181.

Plotnick, Robert, Irwin Garfinkel, Sara McLanahan, and Inhoe Ku. 2004. "Better Child Support Enforcement: Can it Reduce Teenage Childbearing?" Journal of Family Issues 25 (5): 634-657.

Sonenstein, Freya, Joseph Pleck, and Leighton Ku. 1994. "Child Support Obligations and Young men's Contraceptive Behavior: What do Young Men Know? Does it Matter?" Paper Presented at the Annual Meeting of the Population Association of American, Miami May 7, 1994.

Willis, Robert. 1999. "A theory of Out-of-Wedlock Childbearing." Journal of Political Economy 107: S33-S64. 
Table 1: Impact of Ln(Expenditures) on Ln(Births), US Natality Data 1985-1998

$\begin{array}{lcccc} & \text { All } & <\text { HS } & \text { HS } & \text { Some College } \\ \text { Ln(expenditures)*single } & -0.03255 & -0.094 & -0.039 & 0.023 \\ & {[0.0055]} & {[0.010]} & {[0.007]} & {[0.007]} \\ <\text { HS } & -0.0525 & & & \\ \text { HS } & {[0.01075]} & & & \\ \text { Some College } & 0.0188 & & & \\ & {[0.00885]} & & & \\ \text { Black } & -0.42096 & & & \\ & {[0.00892]} & & & \\ \text { White } & 0.57623 & 0.802 & 0.514 & 0.71 \\ & {[0.03475]} & {[0.048]} & {[0.041]} & {[0.047]} \\ \text { Hispanic } & -0.2756 & 0.012 & -0.088 & -0.098 \\ & {[0.03571]} & {[0.049]} & {[0.043]} & {[0.052]} \\ \text { asian } & 0.16181 & 0.695 & 0.068 & 0.085 \\ & {[0.03509]} & {[0.049]} & {[0.041]} & {[0.048]} \\ \text { Single } & -0.85988 & -1.278 & -0.616 & -0.602 \\ & {[0.03728]} & {[0.053]} & {[0.045]} & {[0.050]} \\ \text { Teenager } & -1.47044 & -0.513 & -0.904 & -1.739 \\ & {[0.00946]} & {[0.018]} & {[0.011]} & {[0.012]} \\ \text { Age 20-29 } & 3.59184 & 3.535 & 4.259 & 2.689 \\ & {[0.01123]} & {[0.018]} & {[0.016]} & {[0.019]} \\ \text { Age 30-39 } & 4.05495 & 4.673 & 4.667 & 3.83 \\ & {[0.00795]} & {[0.017]} & {[0.009]} & {[0.010]} \\ \text { Ln(population) } & 3.27318 & 3.236 & 3.504 & 3.139 \\ & {[0.00759]} & {[0.017]} & {[0.008]} & {[0.010]} \\ \text { Observations } & 0.90661 & 0.758 & 0.902 & 0.896 \\ \text { R-squared } & {[0.00385]} & {[0.007]} & {[0.006]} & {[0.007]} \\ & 62026 & 16680 & 17393 & 16041 \\ & 0.91 & 0.93 & 0.97 & 0.96 \\ & & & & \end{array}$

Standard errors in brackets

A vector of 714 state*year fixed effects is included in all regressions

Regressions based on individual births aggregated to state, year, race, age, and education cells 
Table 2

Impact of Ln(expenditures) on Prenatal Investments \& Birth Outcomes, US Natality Data 1985-1998

Ln(expenditures)*single

$<\mathrm{HS}$

HS

Some College

Black

White

Hispanic

asian

Single

Teenager

Age 20-29

Age 30-39

Observations

R-squared 1st trimester

0.01847

[0.00032]

$-0.17752$

[0.00056]

$-0.08365$

[0.00046]

$-0.03683$

[0.00049]

0.01189

[0.00154]

0.09584

[0.00150]

0.01465

[0.00155]

0.0148

[0.00179]

$-0.13702$

[0.00060]

$-0.02757$

[0.00135]

0.02047

[0.00127]

0.04158

[0.00128]

80180

0.91 number of visits

0.08071

[0.00344]

$-1.71384$

[0.00600]

$-0.64377$

[0.00488]

$-0.18678$

[0.00521]

0.10134

[0.01641]

1.15917

[0.01595]

0.16596

[0.01648]

0.19501

[0.01900]

$-1.03312$

[0.00638]

0.01165

[0.01441]

0.01246

[0.01354]

0.05192

[0.01362]

80038

0.89
LBW

$-0.00154$

[0.00012]

0.02879

[0.00021]

0.01509

[0.00017]

0.00647

[0.00018]

0.06202

[0.00058]

0.0066

[0.00056]

$-0.00111$

[0.00058]

0.01646

[0.00067]

0.02737

[0.00022]

$-0.03487$

[0.00051]

$-0.03367$

[0.00047]

$-0.02104$

[0.00048]

80233

0.79

Standard errors in brackets

A vector of 714 state*year fixed effects is included in all regressions

Regressions based on individual births aggregated to state, year, race, age, and education cells 
Table 3: Impact of Ln(expenditures) on Ln(births), Prenatal Investments and Birth Outcomes, US Natality Data 1985-1998

\begin{tabular}{|c|c|c|c|c|c|c|c|c|}
\hline & \multicolumn{4}{|c|}{$\begin{array}{r}\text { Non-Black } \\
\end{array}$} & \multicolumn{4}{|c|}{ Black } \\
\hline & Ln(births) & 1st trimester & visits & LBW & Ln(births) & 1st trimester & visits & LBW \\
\hline \multirow[t]{2}{*}{ Ln(expenditures)*single } & -0.01511 & 0.0183 & 0.0544 & -0.00232 & -0.04744 & 0.01987 & 0.12508 & 0.00031 \\
\hline & {$[0.00534]$} & [0.00037] & [0.00364] & {$[0.00012]$} & {$[0.00816]$} & {$[0.00058]$} & {$[0.00738]$} & [0.00039] \\
\hline \multirow[t]{2}{*}{$<\mathrm{HS}$} & -0.16123 & -0.18048 & -1.62238 & 0.02486 & -0.01642 & -0.18414 & -2.44953 & 0.04905 \\
\hline & {$[0.01049]$} & {$[0.00061]$} & {$[0.00605]$} & {$[0.00020]$} & {$[0.01455]$} & [0.00107] & [0.01359] & {$[0.00072]$} \\
\hline \multirow[t]{2}{*}{ HS } & -0.05608 & -0.07875 & -0.56244 & 0.01335 & 0.2103 & -0.12331 & -1.38734 & 0.02719 \\
\hline & {$[0.00848]$} & {$[0.00049]$} & {$[0.00480]$} & {$[0.00016]$} & {$[0.01364]$} & {$[0.00097]$} & {$[0.01237]$} & {$[0.00065]$} \\
\hline \multirow[t]{2}{*}{ Some College } & -0.43342 & -0.03466 & -0.19049 & 0.00578 & -0.2356 & -0.06526 & -0.52301 & 0.01352 \\
\hline & {$[0.00854]$} & {$[0.00052]$} & {$[0.00514]$} & {$[0.00017]$} & {$[0.01355]$} & {$[0.00102]$} & [0.01297] & [0.00069] \\
\hline \multirow[t]{2}{*}{ White } & 0.04034 & 0.0953 & 1.20375 & 0.00597 & & & & \\
\hline & {$[0.03324]$} & {$[0.00151]$} & {$[0.01489]$} & {$[0.00048]$} & & & & \\
\hline \multirow[t]{2}{*}{ Hispanic } & 0.48434 & 0.01717 & 0.17993 & -0.00047 & & & & \\
\hline & {$[0.03226]$} & [0.00157] & [0.01543] & {$[0.00050]$} & & & & \\
\hline \multirow[t]{2}{*}{ Asian } & -0.61718 & 0.01589 & 0.26076 & 0.01615 & & & & \\
\hline & {$[0.03402]$} & {$[0.00180]$} & {$[0.01774]$} & {$[0.00058]$} & & & & \\
\hline \multirow[t]{2}{*}{ Single } & -1.56094 & -0.13847 & -0.91369 & 0.0258 & -0.52595 & -0.12778 & -1.315 & 0.03519 \\
\hline & [0.00986] & [0.00069] & [0.00681] & {$[0.00022]$} & [0.01356] & [0.00093] & [0.01188] & [0.00063] \\
\hline \multirow[t]{2}{*}{ Teenager } & 3.52408 & -0.0273 & -0.05894 & -0.02645 & 3.8224 & -0.03509 & 0.28164 & -0.07185 \\
\hline & [0.01128] & [0.00147] & [0.01448] & [0.00047] & [0.01197] & [0.00244] & [0.03109] & [0.00164] \\
\hline \multirow[t]{2}{*}{ Age 20-29 } & 3.90212 & 0.02001 & 0.00035 & -0.03044 & 4.15971 & 0.01969 & 0.08084 & -0.05642 \\
\hline & {$[0.00776]$} & [0.00136] & [0.01343] & [0.00044] & [0.00959] & [0.00238] & [0.03033] & {$[0.00160]$} \\
\hline \multirow[t]{2}{*}{ Age 30-39 } & 3.19704 & 0.04094 & 0.04937 & -0.02096 & 3.06756 & 0.04283 & 0.08648 & -0.02192 \\
\hline & [0.00738] & [0.00137] & [0.01349] & [0.00044] & [0.00939] & {$[0.00241]$} & [0.03069] & {$[0.00162]$} \\
\hline Observations & 63473 & 63423 & 63301 & 63473 & 16760 & 16757 & 16737 & 16760 \\
\hline R-squared & 0.91 & 0.9 & 0.89 & 0.58 & 0.96 & 0.94 & 0.93 & 0.62 \\
\hline
\end{tabular}


Table 4: Relationship Between Future Child Support Agreement, Prenatal Transfers and Maternal Investment

$\begin{array}{lcccc} & \text { All } & \text { All } & \text { Constrained } & \text { Unconstrained } \\ \text { Future child support agreement } & 0.085 & 0.08 & 0.101 & 0.088 \\ & {[0.022]} & {[0.022]} & {[0.078]} & {[0.023]} \\ \text { Prenatal transfers from father } & & 0.056 & & \\ & & {[0.025]} & & \\ \text { Maternal Age } & 0.003 & 0.004 & 0.007 & 0.003 \\ \text { Mother }<\text { HS } & {[0.002]} & {[0.002]} & {[0.007]} & {[0.003]} \\ & -0.128 & -0.109 & 0.055 & -0.128 \\ \text { Mother HS } & {[0.070]} & {[0.071]} & {[0.400]} & {[0.072]} \\ & -0.092 & -0.079 & -0.018 & -0.078 \\ \text { Father }<\text { HS } & {[0.067]} & {[0.067]} & {[0.389]} & {[0.068]} \\ & 0.017 & 0.003 & -0.014 & 0.02 \\ \text { Father HS } & {[0.028]} & {[0.029]} & {[0.091]} & {[0.030]} \\ \text { Black } & 0.033 & 0.018 & -0.037 & 0.039 \\ & {[0.025]} & {[0.027]} & {[0.088]} & {[0.027]} \\ \text { White } & 0.049 & 0.058 & -0.451 & 0.092 \\ & {[0.069]} & {[0.070]} & {[0.278]} & {[0.072]} \\ \text { Hispanic } & 0.082 & 0.094 & -0.5 & 0.132 \\ & {[0.075]} & {[0.076]} & {[0.297]} & {[0.078]} \\ \text { Number of children } & 0.118 & 0.12 & -0.507 & 0.175 \\ & {[0.073]} & {[0.074]} & {[0.296]} & {[0.076]} \\ \text { Poverty level } & -0.035 & -0.036 & -0.06 & -0.032 \\ \text { Observations } & {[0.009]} & {[0.009]} & {[0.025]} & {[0.010]} \\ \text { R-squared } & 0.001 & 0.003 & -0.007 & 0.001 \\ & {[0.009]} & {[0.009]} & {[0.047]} & {[0.009]} \\ & 1698 & 1657 & 203 & 1489 \\ & 0.04 & 0.05 & 0.1 & 0.05\end{array}$

Standard errors in brackets

Dependent variable is whether mother initiated prenatal care in the first trimester All regressions include state fixed effects 
Appendix Table 1: Summary Statistics From Birth Certificate Data 1985-1998

\begin{tabular}{|c|c|c|c|}
\hline Single & $\begin{array}{c}\text { All } \\
0.381\end{array}$ & Single & Married \\
\hline prenatal care initiated in 1st trimester & 0.755 & 0.634 & 0.82 \\
\hline number of prenatal visits & 10.9 & 9.9 & 11.5 \\
\hline share LBW & 0.077 & 0.106 & 0.062 \\
\hline$<\mathrm{HS}$ & 0.278 & 0.439 & 0.191 \\
\hline HS & 0.458 & 0.413 & 0.482 \\
\hline Some college & 0.253 & 0.136 & 0.312 \\
\hline white & 0.614 & 0.4 & 0.73 \\
\hline black & 0.184 & 0.375 & 0.081 \\
\hline hispanic & 0.163 & 0.192 & 0.147 \\
\hline
\end{tabular}

